\title{
„Blind football” i (nie)widoczna integracja (nie)widocznych piłkarzy
}

\section{KEYWORDS}

blind football, disability, sport, football, visual impairment

\begin{abstract}
Tomasz Kasprzak, „Blind football” i (nie)widoczna integracja (nie)widocznych piłkarzy [,Blind football" and (in)visible integration of (in)visible players]. Kultura Społeczeństwo - Edukacja nr 2(20) 2021, Poznań 2021, pp. 301-316, Adam Mickiewicz University Press. ISSN 2300-0422, ISSN (Online) 2719-2717. DOI 10.14746/ kse.2021.20.19

"Blind football" was initiated in the last century. What has significantly contributed to its development are newly established organizations, the primary goal of which was to manage various forms of activating people with visual impairment. Popularisation of "blind football" is a long-term, complicated process, in which a plethora of factors are involved. The aim of this article is to reflect on "blind football", especially on the problems with spreading it. Most of all, the article is an attempt to define the mechanism of the functioning of "blind football" in the sphere of meanings of contemporary culture.
\end{abstract}

\section{Wprowadzenie}

Sport osób z niepełnosprawnością został zapoczątkowany w XX wieku, a na jego rozwój szczególny wpływ miały nowo powstające organizacje, których celem było kierowanie oraz zarządzanie różnymi formami aktywizowania osób z dysfunkcjami psychofizycznymi. Na przestrzeni lat zmianom ulegały zarówno warunki, jak i możliwości uprawiania sportu przez osoby z niepełnosprawnością, a kolejne wy-

\footnotetext{
* ORCID: https://orcid.org/0000-0003-0955-3464.
} 
darzenia towarzyszące temu procesowi wyznaczały stopniowe przechodzenie od rehabilitacji przez rekreację do sportu wyczynowego (Niedbalski, 2017a: 115). Taki przebieg rozwoju sportu osób niepełnosprawnych ma swoją kontynuację w jego dzisiejszym rozumieniu. Współczesny sport osób z niepełnosprawnością można rozpatrywać zarówno z punktu widzenia teorii kultury fizycznej, jak i teorii rehabilitacji. Z jednej strony lokuje się go w procesie szeroko rozumianej rehabilitacji, z drugiej zaś jest on integralną dziedziną kultury fizycznej (Niedbalski, 2017b: 46).

Iwona Sikorska, Krzysztof Gerc i Leszek Pawłowski (2017: 8) podkreślają, że rehabilitacyjna funkcja sportu nadal wydaje się być niedoceniania, przede wszystkim w odniesieniu do osób z niepełnosprawnością. Wskazują, że problematycznym staje się wytyczenie precyzyjnych granic sportu wyczynowego, rekreacyjnego i procesu rehabilitacji. Osoby zaangażowane w organizowanie procesu rehabilitacyjnego osób z niepełnosprawnością stają przed pytaniami o różnice dotyczące funkcji sportu dla osób pełnosprawnych i obarczonych niepełnosprawnością, czy też wątpliwościami obejmującymi kompensacyjną funkcję sportu. Początek sportu osób z niepełnosprawnością jest wyraźnie związany z jego funkcją rehabilitacyjną. Impulsem do szerszego wprowadzenia form sportowych $\mathrm{w}$ procesie rehabilitacji chorych była I wojna światowa, w trakcie której prowadzono różnego rodzaju zajęcia sportowe dla rannych żołnierzy z myślą o ich szybszym powrocie na front. W latach 20. i 30. XX wieku rozwijał się ruch sportowy osób z niepełnosprawnością, powstawały kluby sportowe, a także międzynarodowe stowarzyszenia działające na rzecz upowszechnienia sportu wśród niepełnosprawnych. II wojna światowa uświadomiła lekarzom, iż nadspodziewanie dobre efekty daje usprawnianie rannych żołnierzy poprzez sport. Po jej zakończeniu nastąpił dynamiczny rozwój ruchu sportowego osób z niepełnosprawnością, co wynikało z rekordowej w dziejach liczby osób pozbawionych kończyn i sparaliżowanych. Wymuszony w ten sposób postęp masowej rehabilitacji zwrócił uwagę lekarzy na rolę sportu w procesie usprawniania osób z niepełnosprawnością, a także integrowanie ich z pełnosprawną częścią społeczeństwa (Lipoński, 2012: 668; Niedbalski, 2017b: 50). Znaczenie sportu w procesie rehabilitacji osób z niepełnosprawnością dostrzegł lekarz neurolog - sir Ludwig Guttmann - pracujący w szpitalu w Stoke Mandeville. Wprowadził do programu rehabilitacji pacjentów z uszkodzeniem rdzenia kręgowego elementy rywalizacji sportowej w celu zwiększenia ich motywacji do systematycznego udziału w procesie usprawniania. Obserwując duże zainteresowanie swoich pacjentów uczestnictwem w tej formie zajęć, a także ich zaangażowanie w zmaganiach sportowych, 29 lipca 1948 roku (w dniu otwarcia XIV Igrzysk Olimpijskich w Londynie) zorganizował dla swoich pacjentów zawody łucznicze na terenie szpitala, w którym pracował. To wydarzenie przyjęło się 
uważać za początek zorganizowanego, światowego uprawiania sportu przez osoby z niepełnosprawnością. Ludwig Guttmann dążył do nadania międzynarodowej rangi igrzyskom paraplegików rozgrywającym w Stoke Mandeville, zakładając w 1952 roku Międzynarodowy Komitet Organizacyjny Igrzysk Paraplegików. Również dzięki jego staraniom w 1960 roku w Rzymie odbyły się pierwsze letnie igrzyska paraolimpijskie, w których wzięło udział 400 zawodników z 23 krajów (Koper, Tasiemski, 2013: 115; Niedbalski, 2017b: 50)

Początkowo rywalizacja sportowa dotyczyła osób z urazem rdzenia kręgowego (tylko osób z paraplegią), natomiast w kolejnych latach dołączyli do rywalizacji zawodnicy z innymi (i to coraz cięższymi) rodzajami dysfunkcji ruchowych. Równolegle powstawały międzynarodowe organizacje reprezentujące poszczególne grupy sportowców. W 1978 roku powstał Międzynarodowy Związek Sportu i Rekreacji Osób z Porażeniem Mózgowym (ang. Cerebral Palsy International Sports and Recreation Association, CP-ISRA), a w 1980 roku Międzynarodowa Federacja Sportu Niewidomych (ang. International Blind Sports Federation, IBSA). Stopniowo też sport osób z niepełnosprawnością uniezależniał się od ośrodków rehabilitacyjnych. W 1982 roku powołany został Międzynarodowy Komitet Koordynacyjny, którego podstawowym zadaniem było organizowanie kolejnych igrzysk. W roku 1989 powstał Międzynarodowy Komitet Paraolimpijski (ang. International Paralympic Committee, IPC), który od tego momentu reprezentuje sport paraolimpijski na arenie międzynarodowej, odpowiada za jego rozwój na świecie oraz koordynuje wszelkie działania podejmowane w tym kierunku (Koper, Tasiemski, 2013: 114-115).

Chcąc umiejscowić sport osób z niepełnosprawnością w systemie kultury fizycznej, należy odwołać się do form uczestnictwa, jakie w niej występują. Wymienia się wśród nich: wychowanie fizyczne specjalne, rekreację fizyczną, sport oraz rehabilitację ruchową. W przypadku osób z niepełnosprawnością możliwość udziału w różnych przejawach kultury fizycznej determinowana jest specyfiką samej niepełnosprawności, niezależnie od formy tego uczestnictwa zawsze będzie się w niej przewijał cel terapeutyczny. Eli Wolff i Mary Hums (2003) sugerują, że dyskusja na temat możliwości uprawiania sportu przez osoby z niepełnosprawnością powinna koncentrować się na tym, jak tworzyć możliwości, które podkreślać będą zdolności sportowe uczestników zamiast ich niepełnosprawności czy ograniczenia. Rozróżnienie pomiędzy rekreacją a sportem jest często utrudnione, a wynika m.in. z problemów w zdefiniowaniu słowa „sportowiec” w przypadku osób z niepełnosprawnością. Magdalena Koper i Tomasz Tasiemski aktywność sportową osób z niepełnosprawnością ujmują jako „formę uczestnictwa w kulturze fizycznej (rekreacji fizycznej i sporcie), której głównym celem jest utrzymanie 
i rozwój sprawności funkcjonalnej odzyskanej w procesie rehabilitacji leczniczej, a w przypadku osób wyrażających potrzebę współzawodnictwa, dążenie do osiągania jak najlepszych rezultatów" (Koper, Tasiemski, 2013: 116-117; Niedbalski, 2017b: 47).

Na rozwój sportu osób z niepełnosprawnością wpłynęły szersze zmiany zachodzące $\mathrm{w}$ dyskursie politycznym, a zwłaszcza pojawienie się społecznego modelu niepełnosprawności. Obecnie większy nacisk kładzie się na osiągnięcia i umiejętności sportowe osoby z niepełnosprawnością, a organizacje sportowe przyjęły politykę, która formalnie uznaje koncepcję społecznego modelu niepełnosprawności (Macbeth, Magee, 2006). Specyfika sportu osób z niepełnosprawnością polega także na tym, że przy ustalaniu obowiązujących reguł i przepisów sportowych uwzględniane są możliwości funkcjonalne osób o różnym rodzaju i stopniu dysfunkcji (inne u osób niewidomych, a inne u osób $\mathrm{z}$ różnymi schorzeniami narządu ruchu). Istnieją też takie dyscypliny, które są tworzone specjalne dla pewnych kategorii osób z niepełnosprawnością (np. rugby na wózkach dla osób z tetraplegią czy „blind football” dla osób z niepełnosprawnością wzroku). Charakterystycznym elementem, dodatkowo regulującym współzawodnictwo sportowe, jest rozbudowany system klasyfikacji, związany z możliwościami funkcjonalnymi reprezentowanymi przez zawodników z określonym rodzajem i zakresem niepełnosprawności (Niedbalski, 2017b). Kategoryzacja niepełnosprawnych sportowców pozostaje jednak dość kontrowersyjną kwestią. Potrzeba klasyfikowania niepełnosprawnych sportowców w odniesieniu do rodzaju i stopnia niepełnosprawności wydaje się bardziej dostosowana do modelu medycznego, a nie modelu społecznego niepełnosprawności (Macbeth, Magee, 2006). Celem klasyfikacji jest zagwarantowanie uczciwego współzawodnictwa na wszystkich poziomach rywalizacji, co uzyskuje się poprzez zastosowanie odpowiedniego w danej dyscyplinie sportu usystematyzowanego sposobu grupowania zawodników - zgodnie z ich możliwościami funkcjonalnymi. Od lat 40. ubiegłego wieku obowiązywał System Klasyfikacji Medycznej oparty jedynie na diagnozie lekarskiej i polegał na podziale zawodników ze względu na stopień i zakres niepełnosprawności. Od lat 60 . zaczęto rozbudowywać ten system, wprowadzając klasy sportowe dla poszczególnych niepełnosprawności. W latach 90 . przyjęty został System Klasyfikacji Funkcjonalnej specyficznej dla poszczególnych dyscyplin sportowych, według którego oszacowuje się i ocenia możliwości zawodników, uwzględniając jakość wykonania zadań wymaganych podczas współzawodnictwa w konkretnej dyscyplinie sportu. System klasyfikacji zawodników cały czas jest udoskonalany, wychodząc naprzeciw nowym potrzebom rozwijającej się rywalizacji sportowej (Koper, Tasiemski, 2013; Niedbalski, 2017b). 
Istniejące badania dotyczące sportu osób z dysfunkcją wzroku rzadko dotyczącą „blind footballu”. Zatem niniejsze opracowanie ma za zadanie wypełnienie tej luki. Praca poświęcona jest przede wszystkim doświadczeniom niewidomych piłkarzy, którzy poprzez aktywność fizyczną walczą o emancypację - zerwanie ze stereotypem, że osoba z dysfunkcją wzroku jest niezdarna, pełna kompleksów, której podstawowym (i bardzo często jedynym) celem życiowym powinno być permanentne poddawanie się procesom leczenia i rehabilitacji. Celem artykułu jest przybliżenie Czytelnikowi historii „blind footballu”, a także jego podstawowych zasad. „Blind football” stał się symbolem walki o uznanie społeczne sportowców z dysfunkcją wzroku, którzy powszechnie są niewidoczni i niesłyszalni w pełnosprawnym „świecie sportu”. Artykuł zwraca uwagę na rolę „blind footballu" w codziennym pokonywaniu trudności niewidomych piłkarzy, ale przede wszystkim może stanowić przyczynek do dalszej dyskusji naukowej nad tą - jakże złożoną dyscypliną sportową. Reasumując, tekst stanowi próbę spojrzenia na rozwój „blind footballu” jako sportu paraolimpijskiego, w którym niewidomi piłkarze, jak i sama widownia, pełnią rolę katalizatorów zmiany w procesie emancypacji osób z niepełnosprawnościami.

\section{Sport osób niewidomych - obszary tematyczne i nurty badawcze}

Badania dotyczące sportu osób z dysfunkcją wzroku obejmują swoim zakresem wiele zróżnicowanych zagadnień i obszarów tematycznych. W społecznym wymiarze należy wyróżnić kilka podstawowych nurtów badań poświęconych problematyce sportu osób z niepełnosprawnością wzroku.

Pierwszy z nich skupia się na problematyce dotyczącej poziomu aktywności fizycznej u osób z niepełnosprawnością wzroku. W dostępnych badaniach naukowych oceny poziomu aktywności fizycznej osób z niepełnosprawnością wzroku dokonywano na podstawie kwestionariusza aktywności fizycznej lub za pomocą krokomierzy, uwzględniając średnią dzienną liczbę kroków (Rosołek, Gawlik, 2013: 104). W badaniach prowadzonych w ramach tego kierunku zwraca się uwage na niski poziom aktywności fizycznej osób z niepełnosprawnością wzroku (Aslan, Calik, Kitiş, 2012; Ayrazoglu, Oh, Kozub, 2006; Good, La Grow, Alpass, 2008; Green, Miyahara, 2007). Wyniki kierunkowych badań pokazały, że wśród czynników utrudniających podejmowanie aktywności fizycznej przez osoby z niepełnosprawnością wzroku wymienić należy przeszkody środowiskowe, niedostosowane programy aktywności, brak odpowiedniego wyposażenia w klubach fitness czy też 
na basenach, brak informacji przydatnej dla osób z niepełnosprawnością wzroku o obsłudze sprzętu sportowego, a także niski poziom wiedzy instruktorów sportu i rekreacji ruchowej o dostosowaniu zajęć ruchowych do potrzeb tych osób (Rimmer, 2006; Rosołek, Gawlik, 2013).

Następny kierunek jest skoncentrowany na badaniach prowadzonych nad konkretnymi dyscyplinami sportu osób z niepełnosprawnością wzroku. W jego ramach można wydzielić badania dotyczące niewidomych pływaków (Magno e Silva, Bilzon, Duarte, Gorla, Vital, 2013) czy niewidomych i niedowidzących graczy w krykieta (Powis, 2018). Dowodzi się w nich, że osoby z niepełnosprawnością wzroku, które angażują się w aktywność sportową, stają się bardziej świadome swojej cielesności.

W literaturze przedmiotu dużo miejsca poświęca się także badaniom dotyczącym osobistych doświadczeń osób z niepełnosprawnością wzrokową w uczestnictwie w zajęciach wychowania fizycznego (Buckley, Haegele, 2021). Ten obszar badań dał osobom z niepełnosprawnością głos do wyrażania swoich myśli, uczuć, ale także frustracji związanych $\mathrm{z}$ ich osobistymi doświadczeniami z zajęć wychowania fizycznego. Badania te ujawniły zarówno pozytywne, jak i negatywne doświadczenia, jakie osoby z niepełnosprawnością napotkały w trakcie zajęć z wychowania fizycznego (Bucley, Haegele, 2021; Fitzgerald, 2005; Spencer-Cavaliere, Watkinson, 2010). Uczniowie z dysfunkcją wzroku wskazywali, że w trakcie zajęć z wychowania fizycznego doświadczali strachu i frustracji, byli poniżani i dyskryminowani, a czasami czuli się bezwartościowi w oczach nauczycieli wychowania fizycznego (Haegele, Zhu, 2017). Justin Haegele i Xihe Zhu (2017) przeprowadzili badania $\mathrm{z}$ dorosłymi osobami z niepełnosprawnością wzroku na temat ich osobistych doświadczeń z zajęć wychowania fizycznego. Badani wskazywali, że ich nauczyciele postrzegali ich ciała jako „wadliwe”, co miało negatywny wpływ na ich uczestnictwo w zajęciach wychowania fizycznego. Poczucie bycia bezwartościowym i „wadliwym”, które pojawiało się w badaniach analizujących uczestnictwo osób z niepełnosprawnością wzroku (Haegele, 2019; Tanure Alves, Haegele, Duarte, 2018), może prowadzić do rezygnacji czy też unikania zajęć z wychowania fizycznego (Buckley Haegele, 2021). Amanda Yessick i Justin Haegele (2019) wskazują, że dorosłe już osoby z niepełnosprawnością wzroku postrzegały zajęcia wychowania fizycznego jako mało atrakcyjne, a osoby, które chciały być aktywne fizycznie, uczęszczały na zajęcia pozalekcyjne - często już ukierunkowane na osoby z niepełnosprawnością wzroku.

Dysfunkcje narządu wzroku, a także możliwe konsekwencje w postaci niepełnosprawności funkcjonalnej i społecznej stanowią przyczynę ograniczonego dostępu do aktywności fizycznej. Często osoby niewidome i słabowidzące nie mają 
możliwości korzystania z obiektów sportowych, takich jak siłownie, sale gimnastyczne, hale sportowe, baseny. Osoby z dysfunkcjami narządu wzroku nie są w stanie do nich dotrzeć, a ośrodki te nie są przystosowane do ich potrzeb (Tikhonov, 2017, 2020). Andrey Tikhonov (2020) wskazuje, że nawet organizacja domowego treningu fizycznego może być utrudniona, ponieważ wszystkie materiały instruktażowe są opracowane na bazie założenia, że będą wykorzystywane przez osoby widzące. Bierny (czy też mało aktywny) styl życia pod względem aktywności fizycznej, ograniczone samodzielne poruszanie się, niemożność dotarcia i korzystania z usług placówek medycznych, rehabilitacyjnych i sportowych powodują choroby i złe samopoczucie. Z przeglądu literatury przedmiotu wynika, że osoby z niepełnosprawnością wzroku wykazują niższy poziom aktywności fizycznej w porównaniu z osobami pełnosprawnymi, skutkiem czego może istnieć u nich podwyższone ryzyko występowania chorób cywilizacyjnych (Rosołek, Gawlik, 2013). Osoby te są bardziej narażone na takie ryzyko, jak otyłość, sztywność mięśni czy choroby układu krążenia. Brak aktywności fizycznej pogarsza ich stan zdrowia zarówno fizycznego, jak i psychicznego (Tikhonov, 2020). Problemy, które stoją przed sportem osób z niepełnosprawnością wzroku, dotyczą przede wszystkim kwestii związanej z jego sprzecznością ze społecznym statusem osoby z niepełnosprawnością (Niedbalski, 2017a).

\section{„Blind football" - założenia teoretyczne ${ }^{1}$}

Nie widzą bramki, swoich rywali i kolegów z drużyny - tak naprawdę nie widzą nic, a mimo to podają między sobą piłkę i strzelają gole. „Blind football” jest bez wątpienia fenomenem współczesnego świata. Trudno jest dokładnie określić, kiedy i gdzie, odbyły się pierwsze mecze niewidomych piłkarzy. Wynikać to może z faktu, że inicjatywy te nie zaczęły się od profesjonalnych piłkarzy, trenerów (czy

${ }^{1} \mathrm{~W}$ literaturze przedmiotu spotkać można z inne terminy określające „blind football”. Na oficjalnej stronie Międzynarodowego Komitetu Paraolimpijskiego wskazuje się na „piłkę nożną pięcioosobową" (ang. 5-a-side football), natomiast na stronie Międzynarodowej Federacji Sportu Niewidomych wskazuje się na "futsal dla niewidomych” (ang. futsal for the blind lub blind futsal). Judit Gombás (2013) podkreśla, że „piłka nożna pięcioosobowa” to termin, który najlepiej odpowiada wymaganiom politycznej poprawności, gdyż określa rodzaj piłki nożnej poprzez wskazanie liczby członków, nie skupiając się na fakcie, że gracze to osoby z niepełnosprawnością. Z drugiej strony słabość tego terminu polega na tym, że nie przekazuje żadnych dodatkowych, jasnych informacji o samej grze, i także o tym, dlaczego jest tak wyjątkowa. W niniejszym artykule posługuję się terminem „blind football”, aby podkreślić specyfikę tej dyscypliny sportowej, zwracając szczególną uwagę, że dotyczy ona osób z dysfunkcją wzroku, która bez wątpienia ogranicza aktywność fizyczną. 
też nauczycieli), ale miały miejsce w lokalnych instytucjach na rzecz osób niewidomych. Inicjatywy te nie były ustrukturalizowane, mecze były organizowane przez wolontariuszy. Do najbardziej znanych działaczy, którzy upowszechniali „blind football”, zaliczyć należy: Ramona Sausa z Brazylii i Carlosa Campoz Lópeza z Hiszpanii - stworzyli oni m.in. ramy teoretyczne dla tej dyscypliny sportowej. Historia „blind footballu” związana jest z Brazylią, w której to już w latach 50. ubiegłego wieku organizowano mecze niewidomych piłkarzy. Pierwsze zawody $\mathrm{w}$ „,blind footballu" zorganizowane były w Brazylii w 1974 roku z udziałem drużyn z trzech stanów. Kolejne zawody odbyły się w 1980 roku i zorganizowane były przez Stowarzyszenie Rodziców i Przyjaciół Osób Niepełnosprawnych w Brazylii. Ważnym wydarzeniem w promowaniu sportu osób z niepełnosprawnością wzroku było powstanie w 1984 roku brazylijskiego Towarzystwa Sportowego dla Niewidomych. Pierwsze Mistrzostwa Świata w „blind footballu” odbyły się w 1998 roku w Brazylii. Akceptacja „blind footballu” jako sportu paraolimpijskiego podczas Igrzysk Paraolimpijskich w Atenach w 2004 roku była ostatnim ważnym krokiem w rozwoju tego rodzaju sportu na świecie. Jessica Macbeth i Jonathan Magee (2006) jako pierwsi przedstawili ścieżkę kariery niewidomych piłkarzy. Aby wziąć udział w zawodach, niewidomi sportowcy muszą zostać poddani specjalnej klasyfikacji, przeprowadzanej przez lekarza okulistę, gdzie ocenia się ostrość i pole widzenia. $\mathrm{Na}$ jej podstawie niewidomych piłkarzy dzieli się na trzy grupy:

- B1 - brak percepcji światła, a także zdolności rozpoznawania kształtu dłoni $\mathrm{z}$ dowolnej odległości i kierunku;

- B2 - zdolność rozpoznawania kształtu dłoni, ostrość wzroku 20/600 lub pole widzenia poniżej 5 stopni;

- B3 - od ostrości wzroku powyżej 20/600 lub pola widzenia poniżej 20 stopni.

Podział ten oparty jest na klasyfikacji wykorzystywanej przez Światową Organizację Zdrowia (WHO) i akceptowany przez wszystkie dyscypliny sportowe podlegające Międzynarodowej Federacji Sportu Niewidomych. Mateusz Skwierawski wskazuje, że w „blind footballu” grają osoby ociemniałe po chorobach lub wypadkach. Najczęściej mające coś wspólnego ze sportem, trenujące wcześniej amatorsko lub profesjonalnie. Tych, którzy nie widzą od urodzenia, a grają, jest odsetek. Posiadają bowiem problem z koordynacją i wyczuciem sytuacji na boisku. Najważniejszy jest słuch - niewidomi piłkarze korzystają z niego w dwustu procentach. Mecz „blind footballu” składa się z dwóch części po 25 minut (łącznie 50 minut), w trakcie których należy zachować ciszę. W każdej drużynie jest czterech graczy liniowych (B1) i jeden gracz słabowidzący lub widzący (B2 lub B3) jako bramkarz, który pełni rolę przewodnika - „nawigatora” w trakcie meczu - może 
mówić w drużynie, ustawiać zawodników oraz informować o sytuacji na boisku. Aby wszyscy zawodnicy mieli równe szanse, podczas meczu mają zasłonięte oczy. Charakterystycznym elementem „blind footballu” jest piłka, w której znajduje się "grzechotka” - wydająca dźwięk, a tym samym wskazująca jej położenie. W trakcie meczu należy zachować ciszę, jedynie zawodnicy krzyczą hiszpańskie „voy” (co oznacza „idę”) i zgodnie z regułą gry powinno być wypowiedziane głośno i wyraźnie, gdy zawodnik szuka piłki lub znajduje się w jej pobliżu. Przed rozpoczęciem meczu trenerzy powinni upewnić się, że w okolicy boiska nie ma żadnych przeszkód czy też niebezpiecznych przedmiotów. Podczas rozgrywki komunikacja między zawodnikami (a także trenerem) jest jednym z najważniejszych elementów gry (Skwierawski, 2012). Komunikacja w „blind footballu” występuje na dwóch poziomach:

- niewidomy/słabowidzący piłkarz - trener: ważnym jest, aby instrukcje trenera przekazywane zawodnikom były sformułowane w prostym i jednoznacznym komunikacie;

- zawodnik - zawodnik a trener: w „blind footballu” sportowcy muszą odgrywać aktywną rolę w procesie komunikowania się. W trakcie meczu zawodnicy powinni mieć dokładną mapę otoczenia: gdzie jest zawodnik z tej samej drużyny oraz gdzie są przeciwnicy. Gdy gracz nie jest świadomy swojej pozycji, może zawsze wezwać bramkarza lub trenera.

W Polsce „blind football” ma krótką historię. Pierwsze kroki stawialiśmy podczas Mistrzostw Europy w 2015 roku (organizowanych w Wielkiej Brytanii), w których zajęliśmy przedostatnie miejsce - startowało dziesięć drużyn. Obecnie w Polsce działają dwa kluby: Tyniecka NWP Kraków oraz Sprint Wrocław. W listopadzie 2017 roku rozegrany został pierwszy międzynarodowy turniej Ligi Centralnej Europy, w której wzięły udział drużyny z Brna, Pragi, Budapesztu oraz Krakowa i Wrocławia.

\section{(Nie)widoczna integracja (nie)widocznych piłkarzy}

Współczesna kultura (zwłaszcza masowa) promuje i kolportuje model człowieka mocnego, odnoszącego sukcesy, a jednocześnie dysponującego niepospolitą urodą oraz sprawnością. Wpisuje się w to piłka nożna, która związana jest bez wątpienia z „kulturą mężczyzn”, uosabiającą przy tym homogeniczność tej płci. Walka dwóch jedenastoosobowych drużyn na jasno zdefiniowanej arenie (boisku) odwołuje się do archetypowych cech charakteru męskości dominującej, zarówno fizycznych, jak i psychicznych (Melosik, 2015: 313). Historycznie rzecz ujmując, niektóre dy- 
scypliny sportowe były określane jako „męskie”, a udział w nich kobiet czy niepełnosprawnych był wykluczony (bądź w dużej mierze ograniczony). Ten zakładany „naturalny” sport osób pełnosprawnych stanowi przykład jego zmaskulinizowanego charakteru, ale może również stanowić obciążenie, zwiększając presję społeczną na młodych mężczyznach, którzy próbują sprostać oczekiwaniom „bycia mężczyzną". W sporcie utrzymuje się ,ideologia różnicy”, w której męski sport jest często postrzegany jako lepszy od kobiecego. Sportowcy bardzo często uchodzą za bohaterów, którzy stają się obiektem medialnie wspieranego kultu. Taka fascynacja sportem w społeczeństwach nowoczesnych powoduje, że jego najwybitniejsi, a często najbardziej medialni przedstawiciele stają się gwiazdami kultury masowej. Ucieleśniają nasze wyobrażenia o życiu szczęśliwym w bogactwie, luksusie i sławie. Gwiazdy sportu są podziwiane, szanowane i mają w społeczeństwie wysoką pozycję (Dziubiński, 2011: 122; Niedbalski, 2017c: 53). Uwagę na to zwraca Rafał Drozdowski, który podkreśla, że „współczesny sport staje się prawdziwą kwintesencją utowarowienia” (Drozdowski, 2011: 18). Utowarowieniu poddane zostały nie tylko ciała sportowców, ale także ich biografie i medialne wizerunki (m.in. wielomilionowe kontrakty reklamowe gwiazd sportowych, które często okazują się być głównym źródłem ich dochodów). W swoisty towar przekształcono także poziom uwagi i stopień lojalności kibiców (wskaźnik oglądalności wielkich wydarzeń sportowych decyduje o kosztach zakupu praw do transmisji oraz o cenach czasu reklamowego). Badacz podkreśla, że sport jawi się więc jako hiper-rynek, który wszystkie najważniejsze relacje wpisane w jego pole instytucjonalne, szybko i sprawnie podporządkowuje logice transakcji (Drozdowski, 2011: 18-19). Christian Bromberger posługuje się terminem „futbolizacji społeczeństwa”, wskazując, że piłka nożna jest postrzegana i instrumentalizowana jako narzędzie osiągania sukcesów, a nie tylko jako źródło rozrywki i wytchnienia od ważnych spraw życia codziennego (Bromberger, 2001; Stempień, 2020). Piłka nożna przestała być tym czym była (tylko formą rozrywki). Odgrywa coraz większą rolę w innych dziedzinach życia.

Sport osób z niepełnosprawnością - zwłaszcza w ogólnopolskich mediach - do niedawna istniał na marginesie i w cieniu wydarzeń $\mathrm{z}$ udziałem pełnosprawnych sportowców. Jakub Niedbalski wskazuje, że nieco lepiej przedstawia się sytuacja w przypadku lokalnych mediów, które wykazywały (i nadal wykazują) większe zainteresowanie postaciami niepełnosprawnych sportowców. Spore znaczenie dla rozpowszechniania idei sportu niepełnosprawnych od samego początku swego istnienia miały nowe media (ze szczególnym uwzględnieniem social media), które stały się swoistą tubą wykorzystywaną przez samych sportowców oraz osoby z ich środowiska (Niedbalski, 2015: 143). „Blind football” pojawiał się spora- 
dycznie w mediach ogólnopolskich, była to głównie obecność ograniczająca się do krótkich komunikatów z nielicznych wydarzeń sportowych, w jakich brali udział sportowcy z dysfunkcją wzroku. Dlatego też Christina Evaggelinau i Dimitris Grekinis (1998) sugerują, że większa liczba widzów na imprezach sportowych dla osób z niepełnosprawnością może pomóc zaspokoić potrzebę motywacji sportowców podczas zawodów, a także w zmianie negatywnego nastawienia społeczeństwa do tych zawodników.

„Blind football”, pomimo że zbliżony jest do piłki nożnej, charakteryzuje się pewną specyfiką. W przypadku osób $\mathrm{z}$ dysfunkcją wzroku na uwagę zasługuje przede wszystkim ich bardzo ciężka praca, która nigdy nie pozwoli im na osiągnięcie takich wyników, jak w przypadku pełnosprawnych sportowców. Niewidomi piłkarze wykorzystują te same walory sportu - jedynie konkurują z nieco innymi przeciwnikami. Walczą nie tylko z rywalami, ale także z samymi sobą, ze swoimi słabościami oraz rekordami, które kiedyś ustanowili. Ostateczną stawką nie są tytuły mistrzowskie i medale, lecz lepsze życie - nie walczą o wielkie pieniądze, ale ubiegają się o społeczne uznanie. Walczą o emancypację, wyzwolenie z ich ograniczeń, które ciążą na ich szansach życiowych. Owe ograniczenia wynikają w dużej mierze z przyjętego modelu niepełnosprawności - w tym przypadku medycznego. Określenie modelu niepełnosprawności ma decydujący wpływ na działania podejmowane dla jej zapobiegania oraz minimalizowania jej skutków, a także - jak zostaną określone cele edukacji i rehabilitacji osób z niepełnosprawnościami oraz jakie metody będą użyte, aby je osiągnąć. Przede wszystkim jednak - na co uwagę zwraca Andrzej Twardowski - od dominującego modelu niepełnosprawności zależy miejsce osób nią dotkniętych w społeczeństwie i to, w jaki sposób realizowane są ich prawa obywatelskie - do równego traktowania, samostanowienia, edukacji, pracy czy także możliwości uprawiania sportu. Ważnym jest, aby same osoby zainteresowane miały realny wpływ na to, jak niepełnosprawność jest rozumiana przez społeczeństwo i jak są przez to społeczeństwo traktowane (Twardowski, 2019: 8). Dlatego też często zadawane pytanie podczas ważnych międzynarodowych turniejów: „czy nasi reprezentanci zdobędą jakieś medale?” należy uściślić: „czy nasi niepełnosprawni reprezentanci zdobędą jakieś medale?”. Ostateczną stawką nie są tytuły mistrzowskie oraz medale, lecz lepsze życie - nie walczą o wielkie pieniądze, ale o społeczne uznanie. „Blind Football” pomaga osobom z niepełnosprawnością wzroku uwierzyć w istnienie społeczeństwa otwartego, w którym wszystko jest możliwe i które niezależnie od barier mobilności pionowej nie przekreśla szans na ich niezwykłe kariery. „Blind football” coraz częściej postrzegany jest jako sfera, w której dochodzą do głosu i ucierają się nowe wzory oraz reguły porządku, będące zapowiedzią szerszych zmian społecznych. Pojawienie się niewidomych pił- 
karzy na arenach sportowych było dla osób w pełni sprawnych swoistym szokiem kulturowym.

Judit Gombás (2013) przeprowadziła badania dotyczące zaangażowania się osób niewidomych w „blind futsal” na Węgrzech. Ich celem było zebranie informacji o motywacjach niewidomych piłkarzy do angażowania się w ten sport oraz wyzwania przed jakimi stoją jako pionierzy tego rodzaju sportu w tym kraju. Zawodnicy podkreślali, że treningi to idealny czas na spotkania towarzyskie z kolegami z drużyny, które pomagają im zapomnieć o codziennych zmaganiach z niepełnosprawnością. Bardzo często niewidomi piłkarze znali się już wcześniej, ale dopiero wstąpienie do drużyny połączyło ich jeszcze bardziej. Obecnie na Węgrzech „blind futsal” regularnie rozgrywany jest w Budapeszcie. Przywołać należy także badania Keona Richardsona (2020), które koncentrowały się na czynnikach wpływających na udział w rozgrywkach piłki nożnej wśród niewidomych uczniów szkół średnich w Zimbabwe. Uczniowie wskazywali na niewystarczającą liczbę specjalistycznych boisk do piłki nożnej, jak również brak dostępu do obiektów sportowych w kraju. Strach przed kontuzją był postrzegany jako powszechna bariera przed uprawnianiem „blind footballu”. Kontuzje głowy często pojawiały się na początku przygody z tym rodzajem sportu. Natomiast wraz z regularnym uprawianiem „blind footballu” miały miejsce sporadycznie. W istocie strach przed kontuzją mógł w pewnym momencie minąć. Piłkarze skupiali się przede wszystkim na aktywności fizycznej, nawiązaniu bliskich relacji z kolegami z drużyny. Badania pokazały, że większe obawy co do kontuzji mieli rodzice tychże zawodników (Richardson, 2020).

Warto także przytoczyć badania Pála Nádasa (2003), które pokazują, że liczba wykwalifikowanych trenerów pracujących w sporcie z osobami niepełnosprawnymi jest wyjątkowo niska. Trenerzy nie mają informacji oraz specjalizacji w zakresie szkolenia osób niepełnosprawnych, a wielu z nich nigdy nie angażowała się w sport osób niepełnosprawnych. Piłka nożna dla osób z dysfunkcją wzroku, a także inne warianty piłki nożnej osób z niepełnosprawnością powinny zostać wprowadzone już na studiach wyższych dla przyszłych trenerów sportowych.

\section{Podsumowanie}

Bez wątpienia każdy człowiek potrzebuje aktywności fizycznej, która pozytywnie wpływa na stan zdrowotny będący złożoną strukturą składającą się zarówno ze zdrowia fizycznego, jak i psychicznego, społecznego oraz duchowego (Tikhonov, 2020). W literaturze przedmiotu uważa się, że aktywność fizyczna jest szansą tak 
dla indywidualnego rozwoju, jak i społecznej integracji. Poprzez awans na coraz wyższe szczeble współzawodnictwa sportowego, od igrzysk sportowych lokalnych, poprzez igrzyska ogólnopolskie, aż do paraolimpijskich, sport stanowi istotną motywację do pracy nad sobą osoby z niepełnosprawnością (Niedbalski, 2017c; Żukowska, 2006). Wydaje się zatem, że poświęcenie niewidomym piłkarzom więcej czasu $\mathrm{w}$ mass mediach, ale także $\mathrm{w}$ literaturze przedmiotu przyniosłoby korzyści nie tylko samym sportowcom, ale również pozwoliło na stopniową zmianę optyki całego naszego społeczeństwa co do sposobu postrzegania osób z niepełnosprawnością w ogóle. Oczywiście potrzeba dalszych przemian światopoglądowych i świadomościowych członków naszego społeczeństwa, co wymaga nie tylko wzmożonej pracy nad upowszechnianiem idei integracji i normalizacji ze strony mediów, ale też organizacji pozarządowych i powołanych do tego celu agend państwowych. Tylko bowiem w ten sposób możliwa będzie zmiana wizerunku sportu osób z niepełnosprawnością w naszym społeczeństwie (Jabłońska, 2008).

W kontekście aktywności fizycznej należy zauważyć, że osoby z dysfunkcją wzroku prowadzące aktywny tryb życia nadal postrzegane są przez pryzmat czynników osobowościowych, które można traktować jako ograniczające zaangażowanie w poszczególne dyscypliny sportowe, oraz przez pryzmat czynników środowiskowych, które należy rozumieć między innymi jako dostępność sylwetki trenera osoby z niepełnosprawnością na rynku. W kontekście uprawiania „blind footballu” przez osoby z niepełnosprawnością wzroku występują następujące bariery:

- brak zrozumienia i świadomości pełnosprawnych obywateli, jak włączyć osoby z niepełnosprawnością wzroku do sportu;

- ograniczone możliwości w dostępie do programów kształcenia przyszłych trenerów;

- brak dostępnych udogodnień dla niewidomych/słabowidzących piłkarzy, a także ograniczony dostęp do informacji.

Usytuowanie osób z niepełnosprawnością wzroku poza jakąkolwiek aktywnością fizyczną wpływało (i nadal wpływa) na utrwalanie stereotypów o ich bezradności, bezsilności i zależności od innych pełnosprawnych osób. Kontrowersje wokół „blind footballu” jako głównej formy aktywności fizycznej tychże osób wynikały (i bardzo często nadal występują) z segregacyjnego charakteru sportu. Tym samym utrwalany jest stereotypowy obraz niewidomego/słabowidzącego piłkarza - jako mniej sprawnego, niezdolnego do podejmowania akcji czy pozbawionego umiejętności poruszania się po boisku. Poza stereotypową ramą dyskursu „blind footballu”, która wpłynęła na postrzeganie sportowców, coraz częściej mamy do czynienia ze zjawiskiem ignorancji, objawiającej się nieznajomością specyfiki tego rodzaju sportu (szczególnie brak wiedzy wśród ko- 
mentatorów sportowych co do reguł i zasad gry). Bez wątpienia „blind football” stanowi nowy wzór społeczno-kulturowej aktywności fizycznej osób z niepełnosprawnością wzroku. Cechą charakterystyczną „blind footballu” jest brak fetyszyzacji wyników i nakierowanie wysiłków na ich poprawienie. Sport ma pomóc w przełamywaniu własnych słabości, gdyż niewidomy/słabowidzący piłkarz nie bije rekordów świata, nie staje się herosem współczesnych mass mediów, za to staje się kimś więcej - pozwala sobie i nam uwierzyć, że jesteśmy zdolni do przekraczania własnych granic.

\section{Bibliografia}

Aslan U.B., Calik B.B., Kitiş A. (2012), The Effect of Gender and Level of Vision on the Physical Activity Level of Children and Adolescents with Visual Impairment, Research in Developmental Disabilities, 6(33), s. 1799-1804.

Ayvazoglu N.R., Oh H.K., Kozbub F.M. (2006), Explaining Physical Activity in Children with Visual Impairments: A Family Systems Approach, Exceptional Children, 7(2), s. 235-248.

Bromberger C. (2001), Significaciones de la pasión popular por los clubes de fútbol, Buenos Aires.

Buckley M., Haegele J.A. (2021), Experiences in Physical Education and Sport: Reflections of Female Athletes with Visual Impairments, Curriculum Studies in Health and Physical Education, 12(1), s. 67-79.

Drozdowski R. (2011), Sport - podwójny agent, [w:] Ł. Rogowski, R. Skrobacki (red.), Społeczne zmagania ze sportem, Poznań, s. 13-20.

Dziubiński Z. (2011), Kultura masowa a sport: związki i zależności, [w:] Z. Dziubiński, M. Lenartowicz (red.), Kultura fizyczna a kultura masowa, Warszawa, s. 117-132.

Evaggelinou Ch., Grekinis D. (1998), A Survey of Spectators at the International Stoke Mandeville wheelchair Games, Adapted Physical Activity Quarterly, 1(15), s. 25-35.

Fitzgerald H. (2005), Still Feeling a Spare Piece of Luggage? Embodied Experiences of (Dis)ability in Physical Education and School Sport, Physical Education \& Sport Pedagogy, 10(1), s. 41-59.

Gombás J. (2013), Futsal for the Blind: A New Opportunity for Hungarian People with Visual Impairments to Get Engaged in Physical Activity, Applied Studies in Agribusiness and Commerce, 7(1), s. 37-41.

Good G.A., La Grow S., Alpass F. (2008), An Age-Cohort Study of Older Adults with and without Visual Impairments: Activity, Independence, and Life Satisfaction, Journal of Visual Impairment \& Blindness, 9(102), s. 517-527.

Green C., Miyahara M. (2007), Older Adults with Visual Impairment: Lived Experiences and a Walking Group, RE:view Rehabilitation and Education for Blindness and Visual Impairment, (39)3, s. $91-112$.

Haegele J.A. (2019), Inclusion Illusion: Questioning the Inclusiveness of Integrated Physical Education, Quest, 71(4), s. 387-397.

Haegele J.A., Zhu X. (2017), Experiences of Individuals With Visual Impairments in Integrated Physical Education: A Retrospective Study, Research Quarterly for Exercise and Sport, 88(4), s. $425-435$. 
Jabłońska B. (2008), Krytyczna analiza dyskursu na przykładzie debaty „nicejsko-konstytucyjnej” w polskiej prasie, [w:] A. Horolets. (red.), Analiza dyskursu w socjologii i dla socjologii, Toruń, s. 165-184.

Koper M., Tasiemski T. (2013), Miejsce sportu w procesie rehabilitacji osób niepełnosprawnych fizycznie, Niepetnosprawność - zagadnienia, problemy, rozwiązania, 3, s. 111-134.

Lipoński W. (2012), Historia sportu, Warszawa.

Macbeth J., Magee J. (2006), „Captain England? Maybe One Day I Will”. Career Paths of Elite Partially Sighted Footballers, Sport in Society, 9(3), s. 444-462.

Magno e Silva M., Bilzon J., Duarte E., Gorla J., Vital R. (2013), Sport Injuries in Elite Paralympic Swimmers With Visual Impairment, Journal of Athletic Training, 48(4), s. 493-498.

Melosik Z. (2015), Społeczno-kulturowe konstrukcje piłki nożnej: męskość, kolektywna tożsamość i japonizacja, Studia Edukacyjne, 37, s. 313-326.

Nádas P. (2003), A sportolo fogyatékosok és az edzôik helyzete, Magyar Edzô, 1.

Niedbalski J. (2015), Sport osób niepełnosprawnych w przekazie i dyskursie medialnym w Polsce, Przeglad Socjologii Jakościowej, t. 11, nr 2, s. 130-159.

Niedbalski J. (2017a), Niepełnosprawność, [w:] H. Jakubowska, P. Nosal (red.), Socjologia sportu, Warszawa, s. 115-126.

Niedbalski J. (2017b), Wymiary, konteksty i wzory karier. Proces stawania się sportowcem przez osoby z niepetnosprawnościa fizyczna - analiza społecznych mechanizmów (re)konstruowania tożsamości, Łódź.

Niedbalski J. (2017c), Zjawisko marginalizowana sportu osób niepetnosprawnych w wymiarze ekonomicznym, medialnym i społecznym, [w:] J. Niedbalski, M. Racław, D. Żuchowska-Skiba (red.), Oblicza niepetnosprawności w teorii i praktyce, Łódź, s. 41-60.

Powis B. (2018), Visual Impairment, Sport and Somatic Work: The Auditory Experiences of Blind and Partially Sighted Cricket Players, The Senses and society, 13(2), s. 147-162.

Richardson K. (2020), „The Blind can also Play Football”: Factors Influencing Blind Football Participation among Zimbabwean High-School Students with Visual Impairments, Sport and Olympic-Paralympic Studies Journal, 1(5), s. 104-116.

Rimmer J.H. (2006), Building Inclusive Physical Activity Communities for People with Vision Loss, Journal of Visual Impairment \& Blindness, 100, s. 863-865.

Rosołek B., Gawlik K. (2013), Poziom aktywności fizycznej osób z dysfunkcją narządu wzroku a zagrożenie chorobami cywilizacyjnymi - przegląd literatury, Rozprawy naukowe Akademii Wychowania Fizycznego we Wrocławiu, 42, s. 103-108.

Sikorska I., Gerc K., Pawłowski L. (2017), Wstęp. Sport osób z niepetnosprawnościa jako metoda inkluzji społecznej, [w:] I. Sikorska, K. Gerc, L. Pawłowski (red.), Sportowcy z niepełnosprawnością. Aspekty psychologiczne i społeczne, Kraków, s. 7-18.

Skwierawski M. (2012), Idziemy grać w ślepa. Najpierw Beckham teraz Lehmann, https://www.przegladsportowy.pl/pilka-nozna/jens-lehmann-pilka-nozna-dla-niewidomych/qemkvvl, dostęp: 20.03.2018.

Spencer-Cavaliere N., Watkinson E.J. (2010), Inclusion Understood from the Perspectives of Children with Disability, Adapted Physical Activity Quarterly, 27(4), s. 275-293.

Stempień J.R. (2020), The Footballization of the Polish Sociology of Sport, Acta Universitatis Lodziensis. Folia Sociologica, 75, s. 5-13.

Tanure Alves M.L., Haegele J.A., Duarte E. (2018)” „We Can’t Do Anything”: The Experiences of Student with Visual Impairments in Physical Education Classes in Brasil, British Journal of Visual Impairment, 36(2), s. 152-162. 
Tikhonov A. (2017), Uprawianie sportu rekreacyjnego a aktywność społeczna osób z dysfunkcją wzroku. Studium przypadku: Centrum Adaptacyjnych Technologii Regionalnej Organizacji Osób Niepełnosprawnych „Nadieżda”, Ekonomia - Wroclaw Economic Review, 23(4), s. 319-325.

Tikhonov A. (2020), Znaczenie organizacji pozarzadowych jako instytucji zapewniajacych uczestnictwo osób z niepełnosprawnościq wzrokową w aktywności fizycznej, [w:] W. Nowak, K. Szalonka (red.), Zdrowie i style życia. Determinanty długości życia, Wrocław, s. 357-370.

Twardowski A. (2019), Kontrowersje wokół społecznego modelu niepełnosprawności, Kultura - Społeczeństwo - Edukacja, 2(16), s. 7-23.

Wolff E.A., Hums M.A. (2003), Sport Without Disability: Understanding the Exclusion Of Athletes With a Disability, presented at the Annual Conferences of the North American Society for the Sociology of Sport, Montreal.

Yessick A., Haegele J.A. (2019), „Missed opportunities”: Adults with visual impairments' reflections on the impact of physical education on current physical activity, British Journal of Visual Impairment, 37(1), s. 40-49.

Żukowska Z. (2006), Wartości sportu mierzone uczestnictwem młodzieży niepetnosprawnej w igrzyskach paraolimpijskich, [w:] J. Nowocień (red.), Społeczno-edukacyjne oblicza olimpizmu. Ruch olimpijski i niepetnosprawni sportowcy, t. 1, Warszawa, s. 126-134. 